Træk af sundhedspolitikkens genealogi

Distinktion - Tidsskrift for samfundsteori: 3: I sundhedens navn, 2001, 135 sider, 100 kr. www.distinktion.dk

Den moderne vestlige medicin fødes $i$ et komplekst og heterogent netværk af hændelser og processer mellem det 18. og 19. århundrede. I et lidt nærgående historisk perspektiv viser denne undfangelse sig at være intimt forbundet med fremkomsten af den moderne stat og udviklingen af det borgerlige samfund. Derfor kunne den tyske læge, patolog, antropolog og socialmediciner Rudolph Virchow (1821-1902) også erklære, at medicinen i virkeligheden er en samfundsvidenskab, og at politik ikke er andet end medicin i stor målestok. Dette betyder ikke mindst, at den moderne medicins historiske og aktuelle formationer og transformationer må fremstå som et væsentligt samfundsteoretisk genstandsfelt.

På den baggrund bliver det forståeligt, hvorfor tidsskriftet Distinktion, der er hjemmehørende på Institut for Statskundskab ved Aarhus Universitet, udgiver et temanummer om sundhed. Nummerets ansvarshavende redaktører Holger Højlund og Lars Thorup Larsen har valgt at sammenføje denne ambition under overskriften "I sundhedens navn". Efter som perspektivet ikke er sundhedsforskning i en bred forstand, men analyser af sundhedens historiske og aktuelle politiske dimensioner og implikationer, havde en titel som "Træk af sundhedspolitikkens genealogi" i virkeligheden nok været mere prægnant for en karakteristik af temanummerets indhold. Alligevel rammer den originale titel af to grunde noget centralt ved det, som er på spil $\mathrm{i}$ de fleste af tidsskriftets artikler. For det første er sundhedsbegrebets forskellige tematiseringer et væsentligt aspekt ved problematiseringen af sundhedspolitikkens genealogi. De har således ikke blot snævert ontologisk (hvad er sundhed), epistemologisk (hvordan opnås viden om sundhed) og teknisk (hvad er målet for de medicinske praksisser) og dermed sundhedsvidenskabelig relevans, men er også af afgørende betydning for formen og indholdet af de forskellige strategier og taktikker, der gør og har gjort sig gældende for de moderne sundhedspolitikker. For det andet berammer de nærværende analyser af sundhedspolitikkens problematik også et væsentligt perspektiv for en forståelse af den politiske regering af menneskets eksistens, som er kendetegnende for de moderne vestlige samfund. Det er nemlig ikke uden grund, at medicinens sundhedsbestræbelser kommer til at spille en afgørende rolle i den generelle moderne politiske ambition om at optimere menneskelivets kvalitative og kvantitative dimensioner, akkurat som den italienske filosof Giorgio Agamben fremstillede det i sit interessante værk Homo Sacer. Il potere sovrano e la nuda vita fra 1995.

Når der på trods af disse forhold skal holdes fast på en alternativ 
titel, skyldes det ikke mindst, at den franske idéhistoriker Michel Foucault har en fremtrædende tilstedeværelse $i$ en lang række af artiklerne. Han reaktualiserede i 1970'erne den tyske filosof Friedrich Nietzsches genealogi som en kombineret historisk og filosofisk metodik i et forsøg på at beskrive de processer og hændelser, der sammenhængende karakteriserede den vestlige rationalitets historie og betingede det moderne menneskes videnspolitiske status og væsen. Et afgørende element $i$ den samme reaktualisering viste sig at blive fremkomsten af en ambition om at analysere det idéhistoriske fænomen, som Foucault benævnte gouvernementalitet, der tænktes at skulle indfange regeringens (gouvernement) forskellige rationalitetshistoriske former. Tanken var, at den idéhistoriske analyse af regeringen som et bestemt socialog selvteknologisk fænomen kunne fungere som analytisk instrument $i$ en samtidshistorisk afdækning af en række dimensioner ved menneskets ontologi. At det nævnes, skyldes, at Foucaults projekt fungerer som inspiration for en væsentlig - og den mest interessante - del af artiklerne $i$ "I sundhedens navn".

Dette forhold gør sig naturligt nok gældende i den åbnende artikel, som består af en dansk oversættelse af den franske udgave af mesterens eget essay "El nacimento de la medicina social" (Socialmedicinens fødsel), der oprindeligt blev holdt som en forelæsning i Rio de Janeiro i 1974. Samme artikel indskriver sig eksplicit i Foucaults datidige ambition om at analysere biopolitikken som det samfunds- og befolkningsmæssigt orienterede aspekt ved den biomagt, der ifølge Foucault karakteriserer og gennemtrænger de moderne vestlige samfund. En form for magtudøvelse, som er karakteriseret ved en administration og forvaltning af menneskelivet, og som har sin bagside $i$ en administration og forvaltning af døden - i livets navn. I den nærværende artikel undersøger Foucault så fremkomsten af det moderne medicinske system som en afgørende dimension ved den biopolitiske regering af det moderne menneskes eksistens. Nærmere bestemt viser det sig at være et træk ved den moderne medikalisering af samfundet og befolkningen i det 19 . århundrede, nemlig socialmedicinens fødsel, der er på programmet. Dette har ikke mindst sit udgangspunkt i Foucaults afgørende registrering af, at den moderne, vestlige medicin grundlæggende er og fødes som en socialmedicin, som et socialteknologisk kompleks, og at den individualistiske læge-patientorienterede medicin kun er et underordnet element i dette kompleks. Samtidig bliver denne registrering til en afvisning af den udbredte socialhistoriske fremstilling af den moderne, vestlige medicins fødsel som betinget af kapitalismens fremkomst, der krævede en socialisering af kroppen som arbejdskraft. Ikke fordi denne fremstilling er forkert, men fordi kapitalismens udfordring af kroppen som arbejdskraft kun var et, og ikke det 


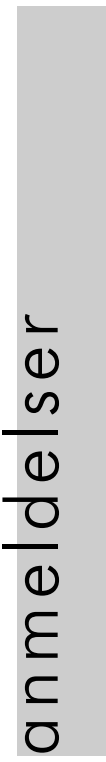

afgørende, element i socialmedicinens fødsel, der nemlig samtidig betingedes af statsvidenskabens fremkomst i Tyskland i det 17. århundrede og af udbygningen af de urbane strukturer i Frankrig i det 18. århundrede. Alligevel viser det sig, at et tredje element, nemlig fremkomsten af arbejdsmedicinen i England i det 19. århundrede, der var betinget af kapitalismen, får en afgørende rolle for udviklingen af de vestlige landes sundhedssystemer.

Foucaults ambition om at analysere den moderne medicins og sundhedsproblematiks funktion og status i og for biopolitikken genfindes så på hver sin måde i yderligere fire af artiklerne i "I sundhedens navn", hvor ambitionen endvidere gives et mere aktualitetsorienteret sigte. I første - og for nærværende bedste - omgang er der tale om et bidrag fra den engelske sociolog Nikolas Rose, der siden 1980'erne har foretaget nogle af de mest interessante og fremtrædende forsøg på at videreudvikle Foucaults regeringsanalytik. I artiklen "Biopolitics in the twenty first century" er det så grundlaget for analyser af biopolitikkens aktuelle former, der sættes på programmet. Nærmere bestemt peger Rose på tre dimensioner, som sådanne analyser må orienteres mod: 1) Den 'genetiske risikopolitik', som henviser til den bestemte tænkeog handlemåde, der karakteriserer den biopolitiske regering af mennesket, som har relation til genteknologiens nuværende udvikling og spredning. Nærmere bestemt formes strategierne for denne regering af en bestemt risikologik, der indebærer, at menneskelivet gøres til genstand for manipulation ud fra aktuelle forsøg på at beregne mulige risici for udviklingen af uønskværdige genetisk relaterede tilstande i fremtiden. 2) Den med genteknologien forbundne biopolitik er så funderet i fremkomsten af et nyt regime for udsigelsen af sandheden om menneskelivet. Rose taler i den forbindelse om tilsynekomsten af en 'molekylær politik', hvilket henviser til ensammenhængendeproblematisering af og omgang med menneskelivet på et molekylærbiologisk niveau. Dermed er der ikke mindst tale om en afdækning og udlægning af livet, som først og fremmest er af teknologisk karakter, hvorfor livet ikke primært erfares i en biologisk naturlighed, men som et fænomen der altid allerede er åbent for skabelse og forandring på dets mikroskopiske plan. 3) Endeligt forbinder biopolitikken sig for indeværende med en 'ethopolitik' som betegnelse for en politisk regering af mennesket, der opererer gennem en regering af det individets regering af sig selv. Med andre ord kan man registrere en kobling mellem individet som biopolitisk subjekt og individet som frit subjekt for sit eget liv, hvor den individuelle etik, den enkeltes eget valg og ansvarlighed, således gøres til et afgørende element $\mathrm{i}$ de politiske sundhedsbestræbelser. Her forener de tre dimensioner sig for Rose $\mathrm{i}$ den helt afgørende pointe - som samtidig sker i markeringen af en eksplicit opposition til Agamben og Baumans parallelisering af vores med eugenikkens tidsalder - at den aktuelle 
biopolitik væsentligt er individualistisk, etisk orienteret, snarere end den er kollektivistisk, som det 19. og 20. århundredes biopolitik, der i større grad var orienteret mod befolkningen som en organisk helhed.

I Lene Kochs artikel "Styring af genetisk risikoviden" er det den første af de, af Rose skitserede analytiske dimensioner ved biopolitikken, der er $\mathrm{i}$ fokus. Her argumenterer Koch således for omkalfatringen af den enkeltes position i sundhedssystemet, og i selvforståelsen som følge af 'genetificeringen' af lægevidenskaben. I en generelt lidt overflødig lighed med Roses artikel vises det først og fremmest, hvordan bærere af bestemte gener samtidig er bærere af en kalkuleret risiko. Den hidtidige vilkårlighed $\mathrm{i}$ hvem, der rammes af sygdom, ændres til en delvist forudsigelig begivenhed, som kan kontrolleres og eventuelt helbredes gennem genetisk viden. Med afsæt $i$ en anvendelse af Foucaults regeringsbegreb gøres det på den baggrund gxldende, hvordan genteknologien er forbundet med fremkomsten af nye regeringsteknologier. Den genetiske viden tvinger os til at vælge mellem muligheder, der er konstrueret af den nyegenetik. Kravetom detinformerede valg gennemsyrer lægevidenskaben og behandlingssystemet. Følelsen af en pligt til viden gennemsyrer individet. Der udvikles nye normer og rationaliteter for omgangen med den nye genetiske viden. Afvisning af viden bliver i stadig højere grad uaccceptabel. I det genetiske risikosamfund er viden etisk set bedre end ikke-viden. Koch afslutter sin spændende artikel med at plædere for en anerkendelse af den ansvarsbevidste og individualiserede borger. Her kunne man måske have ønsket sig en dybere diskussion af lægevidenskabens og medicinalindustriens indsnævring af den enkeltes muligheds- og handlefelt. Paradoksalt nok ender artiklen også med en problematisering af den enkeltes autonomi grundet ansvaret over for den genbærende slægt, hvilket bare er med til at understrege de nye etiske dilemmaer, som genteknologien stiller os over for.

Den tredje af de af Rose skitserede analytiske dimensioner berammer så i det væsentlige genstandsfeltet for Højlund og Larsens artikel "Det sunde fællesskab" og Lise Dahlagers artikel "Forebyggelsens magt". Her er fokus i begge tilfælde den relancering af den positive (sundhedsfremme) og negative (forebyggelse) hygiejne som sundhedspolitiske strategier, der gør og har gjort sig gældende siden 1970'erne som respons på de fortrinsvis politiske, økonomiske og tekniske problemer, der begyndte at karakterisere dels velfærdsstaten og dels det terapeutisk-diagnostiske kompleks, som havde domineret medicinen siden starten af det 20 . århundrede. Et afgørende element $\mathrm{i}$ denne relancering har nemlig ikke blot været en intensiveret opmærksomhed mod sundheden som begreb og fænomen, men også en tiltagende tematisering og operationalisering af den enkeltes eget ansvar for sundhed. 


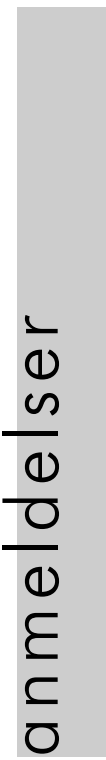

For Højlund og Larsen bliver disse processer så sati relation til en forandret problematisering af samfundets enhed og sammenhængskraft. Nærmere bestemt afdækkes den idéhistoriske opkomst af 'det sunde fællesskab' som en ny social orden, der i højere grad er etisk end retsligt funderet. Med teoretisk udgangspunkt i Robert Castells fremstilling af det sociale spørgsmåls genealogi belyses og diskuteres det således, hvordan ansvaret for den personlige sundhed aktuelt problematiseres som afgørende for den fælles sundhed og dermed for samfundet som helhed. Dahlagers sigte er derimod at fremstille en - lige lovlig tung og formaliseret-udlægning af Foucaults regeringsanalytik med henblik på at kunne afdække de regeringsteknologier, der er på spil i en bestemt empiri, nemlig den livsstilsrelaterede forebyggelsessamtale på Bisbebjerg Hospital. Efter et længere forspil nås der på den baggrund så endeligt frem til den ikke helt overraskende konklusion, at forebyggelsessamtalen involverer etableringen af et bestemt etisk selvforhold for såvel sundhedsprofessionelle som patienter. Temanummerets anden teoretiske omdrejningspunkt er Jürgen Habermas' efterfølger på Institut für Philosophie i Frankfurt, Axel Honneth. I artiklen "Fra anomi til anerkendelse - om den øgede fokusering på depressioner og stigningen af forbruget af antidepressiva" forsøger Anders Petersen og Rasmus Willig at opridse et sociologisk alternativ til psykologiske og medicinske forklaringer på depression og brugen af anti-depressiva. Argumentet er, at samfundets evne til normativ integration kan måles $i$ det stigende forbrug af antidepressiva og $i$ den øgede fokusering på depression. Den franske sociolog Emil Durkheims klassiske anomi-diagnose opdateres med en anden fransk sociolog, Alain Ehrenberg, der ser depressionens karakteristikon som en mislykket definering af egne indre ressourcer; den mislykkede jagt på en selvidentitet $i$ en verden af permanent ubestemthed. Med den franske psykolog Christophe Dejour kobles dette til den nutidige neoliberalistiske konkurrenceøkonomi, der hensætter folk $\mathrm{i}$ en permanent uvished, frygt og usikkerhed. Subjektets normale tilstand $i$ nutiden er derfor karakteriseret ved lidelse; ved den stadige jagt på anerkendelse i konkurrencesituationerne samtidig med, at kravene konstant forskyder sig i et uoverskueligt mønster. Endeligt forbindes diskussionen så med Axel Honneth, som har udviklet en generel teori om anerkendelse, der ikke, som Dejours, udelukkende er koblet til arbejdet. Den nutidige disintegration og destruktion af stabile anerkendelsesstrukturer fører til erosion af subjektets grundlæggende selvtillid, hvor depression opstår. Der er altså et forhold mellem de samfundsmæssige forandringer og noget så individuelt og personligt som depression. I forlængelse af artiklen har Petersen og Willig også foretaget et interview med Axel Honneth, som handler om sociologiens 
rolle i anerkendelsesteorien. Her diskuteres sociologiens empiriske og metodologiske problemstillinger samt dens emancipatoriske potentiale og muligheden for at skabe og opretholde anerkendelsesstrukturer i en tid præget af disintegration og destruktion.

Uden for tema, men diskuterende en del af de øvrige artiklers analytiske grundlag, socialkonstruktivismen, er Michael Hviid Jacobsens artikel "Konstruktionen af socialkonstruktivismen - begrebsforvirring og terminologisk anarki i sociologien". Hviid Jacobsen forsøger at afgrænse og definere socialkonstruktivismen, der er blevet så populær og anvendt, at der er opstået en begrebsforvirring og et terminologisk kaos omkring begrebet. Det gør han ved analytisk at adskille de to diskurser eller niveauer, som den udgøres af: en filosofiskerkendelsesteoretisk, hvis mål er en afdækning af 'sandheden' og en sociologisk-ontologisk, hvis mål er en afdækning af 'virkeligheden'. Hviid Jacobsen slår til lyd for et stærkere fokus på den ontologiske tilgang indenfor sociologien, hvilket illustreres med to eksempler fra hans egen forskning: Den sociale konstruktion af døden og seksualiteten. Hans diskussion og afklaringsforsøg er næsten heroisk givet feltets mangfoldighed og tvetydighed, og hvor han er uklar, er det snarere socialkonstruktivismens uklarhed end Hviid Jacobsens, der skinner igennem. De mange teoretiske og begrebsmæssige fægtninger illustrerer meget godt et grundlæggende problem i den nutidige anvendelse af socialkonstruktivismen og af dens fætter diskursanalysen - et problem som nogle af artiklerne i "I sundhedens navn" også gør sig skyldige i (især Lise Dahlagers artikel og Anders Petersen og Rasmus Willigs artikel): Opstillingen af et enormt begrebsapparat, markeringer og afgrænsninger efterfulgt af en lidt banal analyse, der ikke nødvendigvis har haft behov for den terminologiske opgradering.

Anders Draby Sorensen og Mikekel Thorup

\section{Fokus på sygepleje}

Lisbeth Uhrenfeldt, Vibeke Røn Noer og Sussie Laustsen (red.), Fokus på sygepleje - videnskab og samfund, Munksgaard, København 2002-06-04

"Fokus på sygepleje - videnskab og samfund" er en bogserie, eller snarere en slags årbog, som hvert år samler en række indlæg fra forskere og sygeplejersker med forskningstilknytning, der diskuterer, problematiserer og anskueliggør sygeplejefagets relation til videnskab og samfund. "Fokus på sygepleje 2002" giver et lille indblik $\mathrm{i}$ den forskning, der finder sted $\mathrm{i}$ landets sygeplejemiljøer - hospitaler, sygeplejeskoler og sygeplejefaglige forskningsenheder. Herudover er der også i år bidrag fra eksterne miljøer og udenlandske forskere. Bidragene vidner først og fremmest om en høj metodisk bevidsthed og et grundlæggende kendskab til og anvendelse af relevante teorier. For den filosofisk 